\title{
ARCHITECTURE AND PHILOSOPHY
}

\section{RELATIONS, POTENTIALITIES AND}

CRITICAL POINTS

\section{A B S T R A C T}

In the debate "Architecture and Philosophy / the relations, potentialities and critical points" the notions of "philosophy of architecture" and "aesthetics of architecture" will be discussed. The differences between traditional and contemporary philosophy and aesthetics of architecture will be introduced. In a separate sub-chapter the status of "theory" and "theorizing" during the times of late modernism and postmodern culture will be discussed. It has been pointed to the modalities of theory outside philosophy and aesthetics. The discourses from philosophy, humanities, free theorizing and architectural theories are brought closer together. In the final sub-chapter the status of contemporary philosophy and cotemporary architecture have been discussed. The notion of contemporaneity has been particularly elaborated. The central thesis of this paper is the relation of architecture and philosophy, i.e. the theory constituent for modern, postmodern and contemporary architecture. The derived thesis of the discussion is that critical theory of architecture and architectural yearning for "critical architecture" have acquired exceptional significance at the time of global conflicts and, presently at the time of global economic crisis. The theoretical, aesthetic and philosophical attention has essentially been shifted from the immanent questions about architecture (form, function, spectacularity) to the external i.e. transcendental questions about the culture and society, i.e. about the economy, power, governance, supervision, forms of life, flexibility of architectural production, exchange and consumption. 
ARCHITECTURE AND PHILOSOPHY :

\section{PLATFORMS OF KNOWLEDGE PRODUCTION}

The issues of relations of philosophy and architecture are the issues of deducing the views and of taking the individual view opposite to the general opinion. Deducing and taking the views are the forms of philosophical production. Philosophical production is carried out according to protocols, in procedures and with the effects of views, speech and writing on architecture, namely, on the relations of architecture and philosophy as special and as general knowledge. Philosophical production of views on architecture is most often deduced within the context of philosophy (with the interests of philosophy as a discipline), then, in the context of architecture (with the interests of architecture as a discipline), namely, within the field of the humanities (with the interests of the humanities trans-disciplinary knowledge).

In the western tradition the difference between aesthetics and philosophy of architecture was made and emphasized during the nineteenth century and until the middle of the twentieth century. The philosophy of architecture in the traditional sense was understood as a view which within itself developed the reflection and self-reflection of architecture as separate and general philosophical issue. From diverse philosophical platforms there developed the philosophical reflections of view on the phenomenon of architecture or the phenomenon of the architectural work, on the history of architecture, on economic and political sense of architecture, on the knowledge in architecture or on general conceptions of architectural knowledge, on the language of architecture or semiological analysis of architecture, on architecture as trade, etc. These have been established from the philosophical platforms: epistemology of architecture, semiology of architecture, phenomenology of architecture, Marxist philosophy of architecture, analytical philosophy of architecture, deconstruction of architecture, philosophy of the history of architecture, etc. Opposite to the philosophy of architecture, the aesthetics of architecture in the traditional sense was seen as a philosophical discipline dealing with analysis, interpretation and judging of architectural works in their sensorial modes. Aesthetics of architecture has been understood as a meta-theory of the "theory of architecture", or more often, as a meta-theory of architectural knowledge of forming the architectural work. In other terms, aesthetics was seen as the metatheory of architectural theory of forms in a synchronous and diachronic sense.

However, presently, no difference has been made between the notions of "philosophy of architecture" and "aesthetics of architecture". Philosophy 
and aesthetics of architecture are conceptual and discursive analyses, interpretations, studies or discussions of the general notion or general notions of architecture as contemporary and historical discipline. Thereby, also the protocols of the humanities have been integrated into the field of aesthetics/ philosophy of architecture which leads to the characteristic hybridizing of the theoretical potential of contemporary philosophy/aesthetics of architecture.

Let us move to another issue.

How can one understand the view of architecture? The answers are numerous and diverse. The view can be understood as something which is inseparable from the body which thinks, namely, as a body which deduces the view in respect to architecture. The view can be understood as that which fills up the body transforming it into the human Self (individuum, subject, The Self) in respect to architecture (architectural product, creation within architecture or inhabiting and reception of architecture). The view is recognized, i.e. modeled, as processing, articulation, offer of or deriving of "mental representations" typical of the cognitive order of human mind which is orientated towards something beyond itself, i.e. towards architecture. The view is defined as a certain and uncertain processing of information which leads to acquiring some convictions and beliefs of architecture or anything else associated with architecture. The view can be understood also as that which is other than body, but which together with body forms one actual and potential "Self" of manifestation and action in the real and fictional worlds of architecture as human issue. Thereby, the view can be an understanding, namely bringing the views into relation with other views, speech, writing or media presentation of architecture as concrete or ideal object. Thus, the view is identified as a material social practice. Yet, the view can be understood also as that which (Tell Quel) is above or over the body which in sensuality is placed into brackets so as that which is termed the view can be represented as only the view in respect to the abstracted initial referential object i.e. in respect to architecture. Each of the potential descriptions of the relation of the body and the view is based on deduction of the individual narrative on that which could be the view as practicing the philosophy of architecture. Nadežda Čačinović, the philosopher and aesthetician, points out to the role of "narrative" (giving an account of) as the tool by means of which, against all facts, the effect of credibility can be achieved:

In a certain sense the entire human culture consists of the dilemma between the effect of the story and distrust of it. ${ }^{1}$ 
That is why, still, the philosophy of architecture can be talked about as deduction of reliable and unreliable narratives on the view which references the architecture, and not as the view itself or the relations of the view and the body. Presently, almost the general position is that narrative is what constitutes philosophy and that Socrates subject in philosophy is reached via Plato's narrative, never vice versa. It is believed that philosophy ensues from narrative. The appearance of philosophy is a matter of narrative choices, it is not the matter of philosophy determining narratives, but that the protocol narratives form the philosophy of architecture. When the British philosopher and critic of architecture, Benjamin Andrew ${ }^{2}$ subjects to the analysis the notion "Khora" placed in Plato's dialogue "Timaeus" in relation with deconstruvist debate of architecture potentiality of the French philosopher Jacques Derrida, he faces himself and us as readers with the philosophical narrative and its potential boundaries essential for postmodern architecture. It concerns the protocols and narratives in mutual confrontation. By confrontation of protocols and narratives the philosophical subjectivization takes place, i.e. the notional appearance of Benjamin, Derrida or architect Peter Eisenman. Still further on, such and such Plato, Derrida, Benjamin and Eisenman, who we refer to at some point, is just one of the choices from the deposit of meaning: from one complex archeological projection which seems more like a tangle of discourses or archive of texts than an arranged concept of the historical situating of the Self event. That is why for philosophy the philosopher Plato or the Architect Eisenman are not presented as a "being", but as a discursive figure originated by grouping different discourses in the field of philosophy and the field of architecture. They emerge in the disturbing and hybrid languages and, certainly, in the events of protocol, procedures and effects which provide their oneness of the subject of philosophy and the subject of architecture, i.e. the intrinsic and essential illusion of their completeness and integration in philosophical, architectural, cultural, historical and social reality is provided.

\section{ARCHITECTURE IN THE TIME OF THEORY: THEORY OUTSIDE PHILOSOPHY}

The Time of theory is termed the period following the crisis of high modernism of the 1960s, namely the period of decentering and deconstruction of modern metalanguages ${ }^{3}$ of the society, politics, culture, technics, art and architecture. The time of theory begins with domination from the outside the interior crisis of philosophy and aesthetics reached in modern phenomenology and existentialism. Opposite philosophy, as the integrative system theory of views, the non-systematic theoretical practices of writing and deriving theorizing 
inside special social and cultural areas of action were put in place. It concerns the experimental practices of literature (the magazine Tel Quel, language poetry), it concerns the science and theory on literature (the Yale School, Umberto Eco, Roland Barthes, Gérard Genette), it concerns the theory and practice of painting and visual arts (Support Surface group, Art\&Language group), it concerns the film theory (the French theory and Anglo-American film study: the magazine Cahiers du Cinéma and the magazine Screen), it concerns the theory of gender identities (theory of gender, female studies, gay studies, lesbian studies, queer studies: Julia Kristeva, Judith Butler), it concerns the theory of architecture (Bernard Tschumi, Peter Eisenman), etc. The theory, then, is no longer the external meta-orientated approach to interpretation of art and culture, but the fragmentary contextualization of the knowledge within the paradigms of culture and art. Such understanding of theory develops in the heterogeneous area of theoretical productions of poststructuralism since the late 1960 s until the end of the twentieth century.

The "architecture in the time of theory" syntagm points out to the debate on the role and functions of theory, i.e. theoretical identifications in creation, making, production, exchange and consumption of architecture, i.e. in designing and execution of the form of life. Poststructuralistic theories as well as the contemporary philosophy with variants and hybridized orientations towards the theory of media, theory of body, theory of identity, theory of view, aesthetics of pragmatism, hermeneutics of reading, psychoanalysis of subjectivization, technotheory, the new philosophical phenomenology, cultural theories or philosophical biopolitics, create the turn from interpreting architecture as empirically central issue of aesthetic-formal-utilitarian-technical execution of the living space, i.e. the form of life. According to these new heterogeneous approaches architecture was most often interpreted as a complex multimedia material textual event. It is multimedia since it is perceived not only as a passive space of habitation, but as heterogeneous ideological instrument of constituting of interactive, living and communicational social moment and social reality. Architecture is material, not only by that how the construction building material is shaped, but primarily by being a determined social practice of planning, execution and building of social reality. Architecture is textual since it is structured as a system of signs in complex communication and existential events of forming the human life. It is textual in that sense in which the text is the mode of production of visual, verbal, behavioral, spatial, screen and object meanings. It is an event as the multimedia textual manifestation of architecture occurs in time intervals of constitution of the individual and collective everyday life. 
Architecture is not an aesthetic and aesthetical ideality derived analogously to the concept of autonomous modern work of art. Architecture is an instrument and effect of instrumentalization of constituting the plural (according to JeanLois Lyotard), ideologically determinable reality between political censures and unconscious (according to Louis Althusser). Architecture is an event of specific critical social practices (theory of signifying practice according to Jula Kristeva) and positioning of the subject in the field of differentiation of subjectivity and rationality (psychoanalytical theories in Jacques Lacan tradition). Architecture is a material symptom of constituting the social and political (according to Frederic Jameson ${ }^{4}$, Martin Jay, Slavoj Žižek, Boris Groys), sexual (diverse Freudian and Lacanian traditions, cultural studies), customary (theorizations of archeology of knowledge according to Michel Foucault), technological (according to Jean Baudrillard, Pol Virillio, Félix Guattari) or artistic (according to Victor Burgin) discourse. Architecture is also a polygonal of establishing relative cultural positions between civilization centers and margins (from Derrida's deconstruction of metaphysics to postcolonial critique studies by Edward Said).

Postmodern theories of architecture $^{5}$ appear as opening up of poststructuralistic approaches within the social frame identifying themselves as post-historical and postmetalinguistic ones. That means that the interpretation of architecture is not derived in respect to continuous and orientated history of modernity development. Charles Jencks writes on the death of modern architecture. ${ }^{6}$ Interpretation of architecture is derived in relation to various and inconsistent historical and geographical architectural and artistic traces which become referential ones, both for the postmodern architect (Aldo Rossi, Robert Venturi, John Hejduk, Bernard Tschumi, Peter Eisenman, Charles A. Jencks, Frank O. Gehry) and for the theoretician traversing across the phenomenal or textual presentations of architecture in the field of cultural analysis (Georges Bataille, Roland Barthes, Michel Foucault, Jacques Derrida, Félix Guattari and Gilles Deleuze ${ }^{7}$, Jean-François Lyotard, Jean Baudrillard, Pol Virillio, Frederic Jameson). Postmodern theory of architecture (Charles Jencks) primarily deals with the soft, weak or tangential, and that means multimeaningful and decentered recognition and poetical suggestion of eclectic cited and collage interpretation of relative contextualization (Aldo Rossi) and decontextualizations (Frank Gehry, Zaha Hadid, Daniel Liebeskind) of the architectural work in the post-historical, information/media or globalizing society in which paradoxically there are confronted the regions, multicultural, international and nomadic samples (Jacques Derrida and Peter Eisenman ${ }^{8}$, Bernard Tschumi ${ }^{9}$ ). Theoretical interpretation is nomadic, meaning that 
it manifests itself in the permanent relocation or delaying (différAnce) of the standpoints/points of view of architectural production and theoretical interpretation. Thereby, the theoretical interpretation is not a great meta language of the syntheses of the new building canons, such like it was with the architects-theoreticians of the modern (Gropius, Le Corbusier, Wright). On the contrary, it concerns the multitude of the transitory, floating and transient discourses which simultaneously interpret the questions on architecture and create the atmosphere of architecture in postmodern technology time.

Architecture in cultural studies ${ }^{10}$ presents a significant sample for studying, interpretation and production of the possibility of demonstration of microsocial and everyday executions, functions and effects of production of the living space in the global postindustrial and post-block world. Cultural studies move from macro sociological studies of architecture as social and historical phenomenon of hegemonous western civilization to the questions on microstructures and micro constructions of cultural identities (geographic, racial, ethnic, regional, class, religious, gender ${ }^{11}$, generation one, etc). With the discussion of the context of architecture, from the room micro cell to macro geopolitical urbanism, one comes to problematizing how in a specific artificial space diverse cultural identities are constituted, reflected or presented. For example, how ethnical or professionally status, namely gender individual and micro collective identities are executed/derived in respect to the private or public architectural space. Also, cultural studies problematize the conditions of transfer of geographical architectural identities from one culture into another. Cultural studies are groups of theories having an interpretative academic function, however, also a poetical function in architectural creation, as well as the function of the actual globalizing politics.

Techno-cultural ${ }^{12}$ theories start from the global transformation of the contemporary world by electronic or, metaphorically speaking, digital processing, structure and execution/deriving of the new artificial techno-world. The new artificial techno-world is not a designed metaphor of the future society and its architecture, but the actuality itself in which the modern man lives and acts. That world is the world which by means of aids (machines, instruments, prostheses) transcends from the phase of natural resources processing into the finished products and, thereafter, from the phase of production, distribution, exchange and consummation of information to the built world of modifications of the human being, to the being who is in feed-back relations with the technological system. In techno theories the basic ideas are postulated that the natural world is also the human media structure or, at least, articulation. 
Architecture is no longer interpreted as the set of produced objects, but as a system of machines which realize the actual and visual existential reality of the human body which becomes cybernetically integrated into the living space (Gilles Deleuse, Jean Baudrilard, Pol Virillio). The questions are asked about the cyborg, the Virtual Reality, complex electronic-architectural prostheses by mean of which the human body becomes extended in spatial-time possibilities of existence. As if the techno-theory is demonstrating how the historical architecture has become the material for software simulation of the real and fictional space of existence. ${ }^{13}$

\section{CONTEMPORARY ARCHITECTURE}

\section{AS PHILOSOPHICAL AND POLITICAL ISSUE}

Contemporary architecture is most often the term for the actual architecture, i.e. the architecture which accentuates its contemporaneity. Contemporary architecture "happens" now or in the entirely immediate past.

The "contemporary architecture" concept, essential for the developed modernism immediately following the World War II, is based on interpretations characteristic for highly modernistic criticism, art history and history of architecture. The notion contemporary architecture has been introduced since the differences have been sensed among (1) formations of modernism at the transition from the nineteenth to the twentieth century (secession), (2) the emergence of modernism at the middle of the first half of the twentieth century (avant-garde and modernism of Bauhaus, De Stijl, Russian constructivism, Le Corbusier), and (3) practices of modernism at mid twentieth century (from the International style towards the high and late modernism). These historical differences, namely, different historical formations were supposed to be indexed and redefined at a certain moment, namely separated from the consistent and single-gender modern architecture concept into heterogeneous concepts referenced by the formations of modern, modernism, high modernism, late modernism, and eventually, contemporary art.

The so-called postmodern turn at mid-1970s and during the 1980s was based on the idolized interpretative models of "the end of history", "end of modern society" "14, "the end of art"15 and establishing of "post-history"16, i.e. abolishing the historical understanding of art and architecture by stressing the archival presentation of the past in the present time architectural building. The time line of changes (of the development, revolution) of the modern and modernist architecture has been projected in the spatial order of archives which can be 
indexed and mapped. The historical logics of modernism was replaced in postmodern by the logics of archives ${ }^{17}$, which is presentable as bureaucratically controlled and monitored map which represents, i.e. advocates for different diachronic manifestations in synchrony. In other terms, as if the entire infinitely complex and hybridized past was projected as "the architectural and urban trace" in the contemporaneity where it was arbitrarily "mixed up" or "confused" with the projections of the actual geographic architectural and urban cultures. That blend of the past and contemporary has determined the destiny of the postmodern theorizing of architecture of "post-history" as the necessary reckoning with the modernist historicism and aspirations towards fulfillment of the meaning and function of the history of modern architecture. The reckoning with architectural modernism was not seen as criticism, but as deconstruction of modernism as a form of historicism, i.e. as deconstruction of the project of modernity which appeared as a meaningful and target orientated sequence of movements, schools, manifestations or individual effects in development of modern architectural idealism. In other words, with postmodern theories the deconstructions of "historical development logics" of modernism were derived, although the postmodern architects, artists and theoreticians were extremely fascinated by history. However, for them history was a "trace" or a multitude of floating traces. They dealt with interpretations of arbitrary, dislocated and thereby enticing compounds (pastiche and bricolage) of the history traces and the traces of actuality in which it is possible to link everything again, recombine and multiply. Jacques Derrida in a rhetorically emphasized manner pointed out to the significance of the concept of "dislocation" and "trace". According to Derrida, dislocation ${ }^{18}$ is an event which occurs when something (trace) is forced out of its place (locus) and ceases to be considered an identified place, as added, in space (geography) and time (history).

The attention of the historians, critics and theoreticians of architecture, art and culture was shifted during the 1990s from the "history of immediate past" to interpretation of contemporary architecture, contemporary art and contemporary culture. It was as if the identifiable and determinable world of architecture was expanded into most open and most indefinite movements within synchronous cultures and social formations, namely, as if the cultural and social formations took over the potentiality of the "cultural politics" transforming architecture into one of many cultural practices of making, production, exchange and consumption. The contemporaneity has surpassed the questions on historicity focusing the role of the "contemporary" as the expression or effect, namely the affect of contemporaneity. Instead of historical presentation of the prospective of the contemporary architecture the prospective of "centered and fetishized 
contemporaneity" have been introduced - the contemporaneity of architecture as demonstrated, appropriated or modified testimony on "now" and "here".

Being focused on "contemporaneity" has been shown by various theoreticians in their interpretations of "contemporary art", let us for example consider the interpretations derived by Terry Smith, the leftist liberal theoretician and historian of contemporaneity:

In the aftermath of modernity, and the passing of postmodern, how are we to know and show what is it to live in the conditions of contemporaneity? This is a question about individual being and social belonging now, about how the relationship between them might be understood these days, and how they might be represented to others - in speech, in texts, in works of art, and in exhibitions. ${ }^{19}$

If these Smith's ideas on "contemporary art" are applied to architecture it can be stated that the notion "contemporary architecture" is used as the marking for architecture at the time of globalism, transition and economic crisis at the beginning of the new century. It concerns the architectural situation following modernism and following postmodernism. The basic philosophical question is what the substantial conditions of contemporaneity are, in which way contemporaneity can be interpreted in a critique text, in architectural work or architectural discourses. Modernity and modernism were articulate by rejecting the tradition and deriving the universal actuality, as well as by utopian projection of the immediate ideal or concrete future. In actual theories of "contemporary art" the synchronous moment or interval here and now is historically theorized. In contemporaneity the modern - for example, Hegel's and Marxist - causative historicism are rejected as the summary of concepts on progressive movement and development of humankind, spirit and society and thereby architecture as well. Postmodernist post-historicism and post-historicism as relation towards the past are rejected as well. Contemporaneity is centered and fetishized in relation to the individual and collective self-conscience on its time of culture, technology, architecture and art. Contemporary architecture no longer has the relation towards history and history of architecture, but towards cultural contexts and geographical situations i.e. geopolitical topos of location and dislocation. See the works of contemporary architecture which annul the historical modalities and accentuate the dialogue bit also the conflict with the local geographical, urban, political and cultural milieu: Frank O. Gherry Guggenheim's Museum in Bilbao (1991-1997), Daniel Libeskind The Jewish Museum in Berlin (1988-1999), Norman Foster City Hall in London (1998-2002), Steven Holl Kiasma Museum in Helsinki (19931998), Rem Koolhaas China CCTV Building in Beijing (1999-2995), etc. 
The cultural and architectural exchanges between the first post-capitalist, second post-socialist and transitional, also the third post-colonial worlds are discussed. Contemporary theorizing of "contemporary architecture" has moved from the concepts of history of architecture, supported by aesthetic and poetic discourses, to the concepts of cultural studies and, thereafter, to diverse critical approaches to the political studies. Critic theory of architecture and architectural yearning for "critic architecture" ${ }^{20}$ have acquired an exceptional importance at the time of global conflicts and, nowadays, at the time of global economic crisis. ${ }^{21}$ Theoretical, aesthetic and philosophical attention has essentially been shifted form the immanent questions on architecture (form, function, spectacularity) to the external i.e. transcendental questions about culture and society, i.e. about economics, power, governance, supervision, identity, flexibility of architectural production, exchange and consumption.

In such context architecture and culture are perceived as transitional liberal practices which at the global plan create the situation of the immenseness of phenomena, events, themes, referential potentialities and relations toward the local and global everyday life. At the theoretical plan there happened the switch from history of architecture as an essential theory of architecture to the cultural studies of architecture and art as essential cultural theories, and thereafter followed the switch to the theory of society. These switches were determined by annulling the diachronic in the name of synchronous, namely, from the works it was moved to the text, and from the text to the context, and from the context to the practice being the field of social contradictions and conflicts.

With global economic crisis at the end of the first and beginning of the second decade of the twenty-first century, it was demonstrated that the status of "transitional culture" and "transitional society" were not reserved only for postsocialist and post-colonial societies of the second and the third world, which by globalizations should have been integrated into the neoliberal economic market system, but the developed societies of the West (the USA, EU, Japan, Australia) found themselves in the processes which went beyond their control and transformed the stable order of dominance, supervision and state governance into the unexpected "transitional event" of the de-territorialized networks of corporative interests and capital. ${ }^{22}$ In other terms, the very global system of neoliberal economic market found itself in transition, and that means in crisis situations and events which could potentially lead to various and potentially unexpected directions of resolution. The pressure created by the global crisis had to exacerbate the questions about the critical potentials within 
the contemporaneity of architecture, art and culture. After postmodern as the situation of real or illusionary non-conflicts, architecture has again become the crisis and focal issue of the social, i.e. the power, governance, control, standard, economics, hegemony.

Aesthetician and theoretician of contemporary art, Boris Groys, in the writings "Comrades of Time" presents the following initial question on the identity of contemporary art:

Contemporary art deserves its name in so far as it manifests its own contemporaneity / and this is not simply a matter of being recently made or displayed. Thus, the question 'What is the contemporary art?' implicates the question 'What is the contemporary?' How could the contemporary as such be shown? ${ }^{23}$

In order to answer the questions posed, Groys mobilizes and puts to use different meanings of the word "contemporary". He demonstrates that contemporary does not mean only the presence of now and here, but also the manner in which one can be "with time" unlike of being "in time". Using the German term for the notion of contemporary, zeitgenössisch, he singles out the meaning of the word "genosse“ which means „Comrade“, so that the notion zeitgenössischis is translated as "to be comrade with time“ or ,to be comrade of time“, which means collaborate and interact with time. Thus, if this debate of contemporary art is applied to architecture one can say that not each architecture emerging now and here is contemporary, but that contemporary architecture is the one collaborating with its own time.

That which determines contemporary architecture is not the question of aesthetic or poetic, namely, cultural style in architecture, but in the literary sense phenomenological and functional closeness of modalities ensued from architecture and modalities of organization and reorganization of human life in bio-political ${ }^{24}$ technologies. Phenomenological and functional closeness is achieved in completely uncertain intervals and dislocations of the real space and time which make the actualized global, but not hybridized planetary order. The global order even despite politically promised mass media transparency, exists with certain white and/or dark stains which cannot be read and lead to reason monitored negotiation and agreement. The reason itself and the hope of reason become open to potential perverting by means of "flexible schemes" which replace the invariant abstract political knowledge" (general intellect) and invariance of political, social, cultural, architectural and art institutions in "bio-Darwinism", i.e. in the merciless struggle for survival at the time of 
global crisis, and that means in dialectic vocabulary the total crisis $^{25}$ of the technologies of power and technologies of life shaping.

In this context it is essential also to consider the philosophical consequences of the notion "flexible subject of architecture". The notion "flexible" emerges in one of the early writings by Brian Holmes "Flexible personality - For the New Cultural Critique". The presented theses were later on critically revised by him. Holmes has written an optimistic study with certain criticism additions, whereby the role of "flexible personality" has been recognized as the late effect of the "anti-authoritarian" forms of emancipation in the tolerant conditions of Clinton era in the USA and social-democratic soft aid in Europe. The ideality of "flexible personality" or "flexible culture" was one of really late effects of emancipatory idealizing of "cultural mobility" in the late modernism and trans-national postmodernism. It was discussed about transcultural mobility or about art/cultural nomadism as one of the forms of global emancipation and liberation. But, it was already in the first half of the first decade of the new century, that paradigms of nomadism, mobility, transcultural were transformed in the pragmatic notion of "flexible" (changeable, adaptable) in the field of doing business on the market. Flexible are termed those forms of life or social, cultural, architectural and art practices which are sufficiently changeable and adaptable to survive in the conditions of bio-Darwinist struggle for survival in contemporary neoliberal market orientated society. Finally, Holmes pointed out with critical skepticism that:

The flexible personality represents a contemporary form of governmentality, an internalized and culturalized pattern of 'soft' coercion, which nonetheless can be directly correlated to the hard data of labor conditions, bureaucratic and police practices, border regimes and military interventions. Now that the typical characteristics of this mentality - and indeed of this 'culture-ideology' - have come fully into view, it is high time that we intervene as intellectuals and citizens. ${ }^{26}$

Flexible schemes denote "flexible institutions", deriving the "new flexible personality", i.e. flexible individualization and flexible subjectivization which corresponds to the notions of the new "flexible work" and "flexible economics" - which is often termed crisis, i.e. unstable "post-Fordist work" ${ }^{27}$ and "immaterial work" 28 or "cognitive work" within unstable conditions of market struggle.

It is my thesis that "contemporary" in relation to the time of the global economic crisis can be termed the spatial-time life flexibility which instantaneously 
gets modified, adapts itself, dislocates and temporalizes in relation to critical and crisis social stimuli. Whereas Groys, at the time of almost unquestioned domination of neoliberal flexible and abstracted system of economic power which dictates the character of all activities, recognized "contemporary" as the concord with the time and not necessarily being in time, today amidst one of the peaks of the crisis - which between 2011 and 2012 emerged as an opaque screen towards the future - "contemporary" is identified as really instantaneous reaction to the catastrophically altered situation. 12-22. ed. K.M. Hays (Cambridge MA: The MIT Press, 1998): pp. 440-461. 
Diana Agrest, ed., The Sex of Architecture (New York: Abrams, 1996); Peg Rawes, Irigaray for Architects (London: Routledge, 2007).

Manuel Gausa, Vicente Guallart, Willy Müller etc, Metapolis Dictionary of Advanced Architecture: City, Technology and Society in the Information Age (Barcelona: Actar editorial, 2003).

C.H. Gray, ed., The Cyborg Handbook (New York: Routledge, 1995).

Francis Fukuyama, The End of History and the Last Man (New York: The Free Press, 1992).

Arthur C. Danto, "The End of Art", in The Philosophical Disenfranchisement of Art (New York: Columbia University Press, 1986): p. 107.

Arthur C. Danto, „Introduction: Modern, Postmodern, and Contemporary“, in After The End of Art - Contemporary Art and the Pale of History (Princeton NJ: Princeton University Press, 1997): p. 12 .

Sven Spieker, The Big Archive - Art from Bureaucracy (Cambridge MA: The MIT Press, 2008). Jacques Derrida, ,Struktura, znak i igra u obradi ljudskih znanosti“, u Suvremene književne teorije, ed., Miroslav Beker (Zagreb: Matica Hrvatska, 1999): p. 211.

Terry Smith, Okwui Enwezor and Nancy Condee, „Preface“, in Modernity, Postmodernity, Contemporaneity (Durham: Duke University Press, 2008): p. xiii.

William J. Lillyman, Marilyn F. Moriarty and David J. Neuman, eds., Critical Architecture and Contemporary Culture (New York: Oxford University Press, 1994).

Mark Dorrian, 'Introduction: Criticism/Negation/Action", in Critical Architecture, eds., Jane Rendell, Jonathan Hill, Murray Fraser, Mark Dorrian (London: Routledge, 2007): pp. 11-13.

Rem Koolhaas, ed., Content (Köln: Taschen, , 2004).

Boris Groys, "Comrades of Time”, in Are You Working Too Much? Post-Fordism, Precarity, and the Labor of Art, eds., Julieta Aranda, Brian Kuan Wood and Anton Vidokle, e-flux journal (Berlin/ New York: Sternberg Press, 2011): p. 23.

Paolo Virno and Michael Hardt, eds., Radical Thought in Italy - A Potential Politics (Unuiversity of Minnesota Press, 1996).

Maurizio Lazzareto, “On the Crisis: Finance (or Property Rights) versus Social Rights”, in Meaning Liam Gillick, ed., Monika Szewczyk (Cambrdige MA: The MIT Press, 2009): pp. 147-156.

Brian Holmes, „, The Flexible Personality for a new cultural critique“, from Hieroglyphs of the Future / art \& politic s in a newtworked era, WHW and Arkzin, Zagreb and Paris, 2003, pp. 106145.

Fleksibilna ličnost - za novu kritiku kulture“, from Hijeroglifi budućnosti - umjetnost i politika u doba umreženosti, WHW and Arkzin, Zagreb and Paris, 2003, p. 131.

Paolo Virno, Gramatika mnoštva - prilog analizi suvremenih formi života, Jasenski and Turk, Zagreb, 2004; Pascal Gielen, Paul De Vruyne (eds), Being an Artist in Post-Fordist Times, Nai Publishers, Rotterdam, 2009.

Maurizio Lazzarato, "Immaterial Labour.”, http://www.generation-online.org/c/fcimmaterial labour3.htm. 
Agamben, Giorgo. Potentialities - Collected Essays in Philosophy. Stanford Cal: Stanford University Press, 1999.

Agrest, Diana. Ed., The Sex of Architecture. New York: Abrams, 1996.

Alison, J., M-A Brayer, F. Migayrou and N. Spiller. Eds., Future City - Experiment and Utopia in Architecture. London: Thames \& Hudson, 2006.

Ballantyne, A. Deleuze \& Guattari for Architects. London: Routledge, 2007.

Benjamin, Andrew. ed., "Philosophy a nd Architecture" in Journal of Philosophy and the Visual Arts. New York: Academy Editions London, St. Martin's Press, 1990.

Benjamin, Andrew. ed., "Philosophy and Architecture", in Journal of Philosophy and the Visual Arts. London, 1990.

Benjamin, Andrew. Architectural Philosophy. London: The Athlone Press, 2000.

Benjamin, Andrew. Writing Art and Architecture. Melbourne:Rre-press, 2010.

Brunette, P., and D. Wills. eds., Deconstruction and the Visual Arts - Art, Media, Architecture. Cambridge/New York: Cambridge University Press, 1994.

Cacciari, M., Architecture and Nihilism: On the Philosophy of Modern Architecture. New Haven: Yale University Press, 1993.

Coyne, R. Derrida for Architects. London: Routledge, 2011.

Defert, D. "Foucault, Space, and the Architects", in Document X - the book. Cantz Kassel, 1997, pp. 274-284.

Deleuze, Gilez. Difference and Repetition. New York: Columbia University Press, 1994.

Deleuze, Gilez and Felix Guattari. A Thousand Plateaus - Capitalism and Schizophrenia. London: Continuum, 2002.

Dodds, G. and R. Tavernor. eds., Body and Building - Essays on the Changing Relation of Body and Architecture. Cambridge MA: The MIT Press, 2002.

Foucault, Michel. "The Thought of the Outside", in Michel Foucault: Aesthetics, Method, and Epistemology - Essential Works of Foucault 1954-1994, ed. James Faubion. New York: The New Press, 1998, pp. 147-169.

Foucault, Michel. "Different Spaces", in Michel Foucault: Aesthetics, Method, and EpistemologyEssential Works of Foucault 1954-1994, ed. James Faubion. The New Press, 1998, pp. 175-185.

Gausa, Manuel, Vincent Guallart, W. Müller and F. Soriano, Metapolis Dictionary of Advanced Architecture: City, Technology and Society in the Information Age. Barcelona: Actar editorial, 2003.

Grosz, Elizabet. Architecture from the Outside - Essays on Virtual and Real Space. Cambridge MA: The MIT Press, 2001.

Hays K.M. ed., Architecture - Theory / since 1968. Cambridge MA: The MIT Press, 1998.

Heidegger, Martin. "The Origin of the Work of Art", in Martin Heidegger-Basic Writings, ed. D.F. Krell. London: Routledge \& Kegan Paul,1978. pp. 143-187.

Heidegger, Martin. "Building Dwelling Thinking", in Martin Heidegger - Basic Writings. ed. D.F. Krell. London: Routledge \& Kegan Paul,1978. pp. 319-339.

Kipnis, Jeffrey, T. Leeser. eds. Chora L Works / Jacques Derrida and Peter Eisenman. New York: The Monacelli Press, 1997.

Koolhaas, Rem. S, M, L, XL. New York: The Monacelli Press, 1998.

Ibid., "Junkspace", October no. 100. New York, 2002, pp. 175-190.

Ibid. ed., Content. Köln: Taschen, 2004.

Lamster, M. ed., Architecture and Film. New York: Princeton Architectural Press, 2000.

Leach, Neil. ed., Rethinking Architecture - A Reader in Cultural Theory. London: Routledge, 1997.

Lillyman, W.J., M.F. Moriarty and D. J. Neuman. eds., Critical Architecture and Contemporary Culture. New York: Oxford University Press, 1994.

Nesbitt, K. ed., Theorizing a New Agenda for : An Anthology of Architectural Theory 1965-1995. Princeton NJ: Princeton Architectural Press, 1996.

Puglisi, L.P. New Directions in Contemporary Architecture: Evolutions and Revolutions in Building Design Since 1988. West Sussex: John Wiley \& Sons, Ltd, 2008.

Rawes, P. Irigaray for Architects. London: Routledge, 2007.

Rendell, J., J. Hill, M. Fraser and M. Dorrian. eds., Critical Architecture. London: Routledge, 2007.

Sharr, A. Heideger for Architects. London: Routledge, 2007.

Tafuri, Manfredo. Theories and History of Architecture. London, 1980.

Tschumi, Bernard. Arhitektura i disjunkcija. Zagreb: AGM, 2004.

Vidler, Antoni. The Archiotectural Uncanny - Essays in the Modern Unhomely. Cambridge MA:

The MIT Press, 1994.

Wijdeveld, P. Ludwig Wittgenstein Architect. Amsterdam: The Pepin Press, 2000. 
ESTETIKA U ARHITEKTURI:

SAVREMENA ISTRAŽIVA`KA PITANJA

\title{
Vladimir Mako
}

Cilj ovog članka je da pruži osvrt u vezi sa istraživanjima pitanja estetike vezanim za arhitekturu, urbano projektovanje, kao i životnu sredinu u opštem smislu. U tu svrhu, članak se fokusira na period poslednjih dvanaest godina, kao period intezivnih istraživanja navedenih pitanja korišćenjem novih filozofskih stavova i vrednosti interkulturalnosti. Čini se da je u tom periodu istraživanje estetike arhitekture pomereno u složena interdisciplinarna polja razvijajući nove teorijske ideje a u isto vreme obogaćujući procese kreativne prakse.

KLJUČNE REČI: ESTETIKA, ARHITEKTURA, URBANO PROJEKTOVANJE, ŽIVOTNA SREDINA, ISTRAŽIVANJE

UMETNOST I ESTETIKA: TRI SKORAŠNJE PERSPEKTIVE

\begin{abstract}
Aleš Erjavec
Autor skicira razvoj odnosa između umetnosti i estetike u nedavnoj prošlosti. Kao svoju polaznu tačku on uzima stanovište koje su umetnici ustanovili šezdesetih godina u odnosu na filozofsku estetiku. Po njegovom mišljenju 1980 godina je predstavljala istorijski početak što se tiče transformacija i u umetnosti i u filozofiji. On zatim razmatra tri teorije umetnosti i estetike „relacionu estetiku“ Nikolasa Burioda iz devedestih, estetski projekat Žaka Ransijera iz naredne decenije i najskoriju ,teoriju savremene umetnosti“ koju je razvio Teri Smit. Po autorovom mišljenju, ove tri teorije estetike i umetnosti ne samo da opovrgavaju prožimajuće mišljenje da je savremena estetika shvaćena kao filozofija umetnosti još jednom odvojena od savremene umetnosti i sveta umetnosti, ali isto tako jasno ispoljavaju njihov faktički značaj i uticaj u savremenim diskusijama o umetnosti.
\end{abstract}

KLJUČNE REČI: UMETNOST, ESTETIKA, RELACIONA ESTETIKA, ŽAK RANSIJER, TERI SMIT, SAVREMENA UMETNOST

ARHITEKTURA I FILOZOFIJA

Odnosi, potencijalnosti i kriti`na mesta

\section{Miško Šuvaković}

U raspravi "ARHITEKTURA I FILOZOFIJA / odnosi, potencijalnosti i kritična mesta" biće reči o pojmovima "filozofija arhitekture" i "estetika arhitekture". Biće uvedene razlike između tradicionalne i savremene filozofije i estetike arhitekture. U posebnom potpoglavlju se razmatra status "teorija" i 
"teoretizacija" u vremenu poznog modernizma i postmoderne kulture. Kazuje se na modalitete teorije izvan filozofije i estetike. Približavaju se diskursi iz filozofije, humanističkih nauka, slobodnih teoretizacija i arhitektonskih teorija. U završnom potpoglavlju se razmatra status savremene filozofije i savremene arhitekture. Posebno se razrađuje pojamj savremenosti. Centralna teza ovog rada je da je odnos arhitektiure i filozofije tj. teorije konstitutivan za modernu, postmodernu i savremenu arhiutekturu. Izvedena teza rasprave je da kritička teorija arhitekture i arhitektonska žudnja za "kritičkom arhitekturom" su dobile izuzetan značaj u vremenu globalnih konflikta i, danas, u vremenu globalne ekonomske krize. Teorijska, estetička i filozofska pažnja se suštinski pomerila pomerila sa imanentnih pitanja o arhitekturi (forma, funkcija, spektakularnost) na spoljašnja tj. transcendentna pitanja o kulturi i društvu, tj. o ekonomiji, moći, upravljanju, nadzoru, oblicima života, fleksibilnosti arhitektonske proizvodnje, razmene i potrošnje.

KLJUČNE REČI: ARHITEKTURA, FILOZOFIJA, ESTETIKA, TEORIJA, HUMANISTIKA, ZNANJE, VREME TORIJE, SAVREMENOST, SAVREMENA ARHITEKTURA

ARHITEKTURA KROZ SPORT

\section{Lev Kreft}

Može se naći određena paralela između arhitekture i sporta u istoriji (Rim) i savremenom dobu koje nosi sportski spektakl kao globalno najveći vid zabave, i prepoznatljive arhitekture sporta kao znaka njegovog opšteg prisustva. Olimpijske igre 2012.g. u Londonu pratile su slogan „Arhitektura za čovečanstvo", dodajući ekološku i društvenu zabrinutost tradicionalnoj ideji sportskih objekata kao modernih katedrala. Arhitektura sporta postala je iskaz koji otelovljuje ideologiju koja sport pretvara u razlog nadanja. Arhitektura sporta nastala je u polju u kom standardizacija prostora (i vremena) postoji više od sto godina, zajedno sa koncentracijom moći u sportskim udruženjima koja su, tokom ovih sto godina, promenila svoj identitet iz pokreta civilnog društva u institucije kapitalizma. Originalno značenje ,sporta“ (desportes, deport) kao aktivnosti van redovnog i uobičajenog svakodnevnog života produženo je u nove domene prostora i vremena u kojima se proizvodi zabava masovnih medija. Savremena arhitektura sporta mora da prati posebna prostorna pravila i zahteve sportskih igrališta i pravila medijskog prisustva. Mesta sporta su mesta gde masivna publika gleda utakmicu i gde posmatra sebe kako posmatra - biti viđen od strane mase čije je virtuelno prisustvo danas možda najvažniji interes projektovanja arhitekture sporta. 